\title{
3. Social and Environmental
}

Transformations in the

Neighbourhood of a Nickel Mining

Project: A Case Study from

Northern New Caledonia

MATTHAS KOWASCH

\section{Introduction}

The irony of 'poverty in the midst of plenty' can be applied to many developing and emerging countries rich in mineral resources. The resource curse thesis 'correlates natural resource abundance to evidence of slow or declining economic growth' (Langton and Mazel 2012: 24; see also Auty 1993; Sachs and Warner 1995; Freudenburg and Wilson 2002; Bebbington et al. 2009). Raw materials such as copper, nickel, gold and uranium are found and widely exploited in regions inhabited by indigenous peoples who live far from the centres of political power. In most cases, the mining sector offers few economic benefits for the indigenous peoples, even if mine operators promise to provide opportunities for social, educational and economic development. In their study of the Pilbara region in Western Australia, Taylor and Scambary (2005: 28) note: 'While the 
regional labour market has grown in both size and complexity, indigenous participation has remained relatively marginal'. The relationship between mining companies and indigenous communities is largely based on an unequal relationship of power. Even if multinational companies have become increasingly aware of the importance of corporate social responsibility, indigenous communities are in most cases characterised by weakness in the face of these companies. Taking examples from Papua New Guinea, Colin Filer postulates a process of 'social disintegration' within such indigenous communities (Banks 1996: 233).

The French overseas territory of New Caledonia possesses around 25 per cent of worldwide nickel deposits, and mining products represent around 95 per cent of its total exports. Economic development and the nickel industry depend on each other. Historically, indigenous Kanak people were excluded from the mining industry in New Caledonia, while the land was forcibly occupied for farming and other economic activities. Discriminatory regulations were abolished after World War II, and Kanak people progressively became French citizens. They also got jobs in the mining sector, especially as truck drivers or cleaners. The only nickel smelter at that time was the Doniambo plant in Nouméa, which was operated by the French company Sociéte Le Nickel (SLN). This situation changed in the 1990s. The demands of the independence movement for economic development and political emancipation from France resulted in the Koniambo project in North Province.

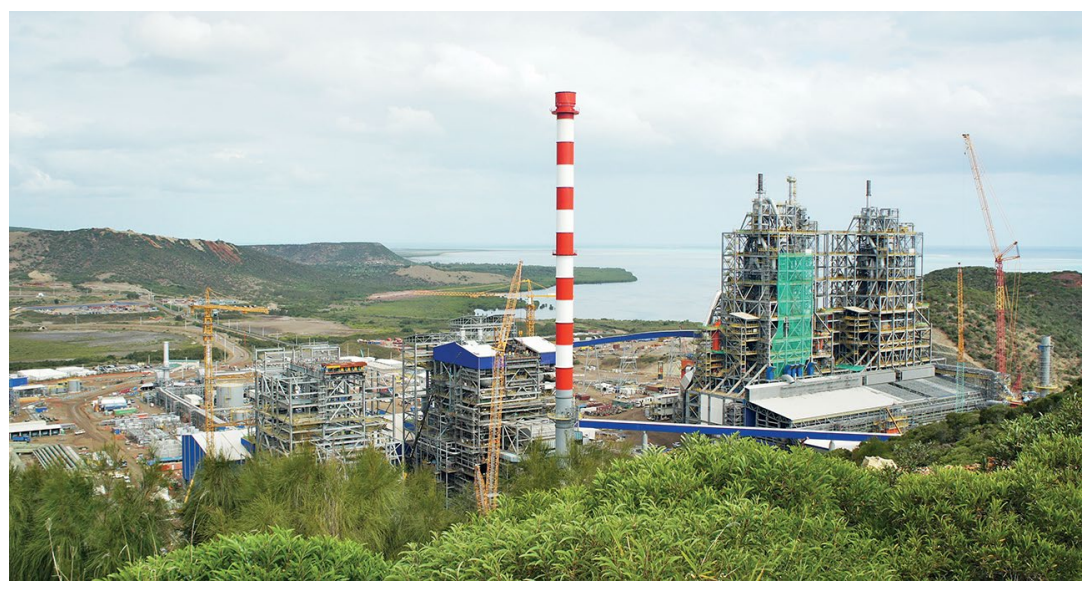

Figure 3.1 The Koniambo project construction site, September 2012. Source: Photo by Matthias Kowasch. 
North Province, which is governed by the Kanak independence umbrella party Front de Libération Nationale Kanak et Socialiste (Kanak and Socialist National Liberation Front), became the majority shareholder in the project. A majority shareholding means more decision-making power and more influence over the strategy of the mining company or its shareholders. But involvement in the nickel sector will not preclude societal transformations occurring within the Kanak communities living in the neighbourhood of the project. On the contrary, employment, business creation and shareholding lead to social upheaval.

After describing the emergence and background of the Koniambo project in northern New Caledonia, this chapter focuses on societal and environmental transformations within the indigenous communities in the neighbourhood of the project. In 2003, Leah Horowitz completed a $\mathrm{PhD}$ thesis about the relationship between the Koniambo project and the closest Kanak village, Oundjo, which is only 2 kilometres from the work site (Horowitz 2003a). Drawing upon this ethnographic study and the papers of other authors working on societal transformations in neighbouring Kanak communities (Emergences 2009a, 2009b; Poithily 2010; Grochain and Poithily 2011; Le Meur et al. 2012; North Province 2013), this chapter is based on more than two years of fieldwork and various research projects conducted at the Institut de Recherche pour le Développement (IRD) between 2007 and 2012. ${ }^{1}$ The present chapter sets out the involvement of neighbouring Kanak communities in the Koniambo project, through employment, business creation and subcontracting, and describes conflicts linked to the construction of the nickel smelter. Social and environmental transformations within the communities are analysed in a theoretical framework outlined in the next section.

\section{Method and Theoretical Framework}

Fieldwork in post-colonial settings is subject to special rules and presents very particular challenges to the researcher. The French overseas territory of New Caledonia is a country, inscribed since 1986 on the United

1 I would like to thank the IRD branch in Nouméa, especially the research groups UMR Espace-DEV and UMR GRED for logistical support, welcome and encouragement during my $\mathrm{PhD}$ and subsequent research projects. In the framework of different research programs (GERSA, Mining Governance), financial grants helped me to conduct the surveys. I received warm welcomes from families in the four villages where I worked. I would like to particularly thank my family in Baco, where I lived for a year. 
Nations (UN) list of 'non-self-governing territories' (see article 73 of the UN Charter). The long history of relations between the indigenous Kanak independence movement and the UN has been described by Christine Demmer (2007) and Stéphanie Graff (2012). The civil war in the 1980s, the independence movement and the process of decolonisation have to be considered by researchers who undertake ethnographic studies in Kanak communities. The theft of intellectual property represents a danger that the researcher also has to consider when doing fieldwork. According to Paul Robbins (2006: 313), research in the global South can be a postcolonial and expropriating act. When I started fieldwork in the Kanak village of Baco, clan elders mentioned that it is important to share the results of research studies with the communities themselves. Kanak communities often welcome European researchers who are interested in obtaining information about clan histories, sacred places, and local people's perceptions and ideas-in short, 'intellectual property'.

My fieldwork in northern New Caledonia was part of a $\mathrm{PhD}$ thesis in human geography (2006-10), other research projects and a consultancy undertaken for the authorities of North Province in 2012. A quantitative survey of 239 people in four Kanak villages (Netchaot, Baco, Oundjo and Gatope) was carried out from 2008 to 2010 (see Figure 3.2). Young volunteers from the villages were recruited as interviewers for the study. The quantitative approach was complemented by semi-structured interviews with businessmen, customary authorities and politicians. I collaborated with customary authorities to map sacred places and clan housing in order to visualise territorial perceptions in the vicinity of the mining project. We pointed out the places with a global positioning system or on a paper map before exporting the data to a geographical information system. The challenge was to develop a method of spatial analysis to map the heritage values attributed to places by Kanak people and to make this new information available for regional planning programs. A real partnership means having enough space for views to be expressed by both the researcher and the customary representative. Both play the parts of 'learner' and 'teacher' at the same time (Kowasch 2014: 261). Collaboration with customary authorities and representatives is consistent with the conclusion of the political ecologist Piers Blaikie (2012: 237), who suggests that 'the notion of a politicised organigram is sometimes useful to understand what "really goes on" in a relevant part of an administration' (2012: 37). And the regular presentation of research results in Kanak villages underlines the point that researchers can 'give something back' to local populations (Kowasch 2014: 262). 


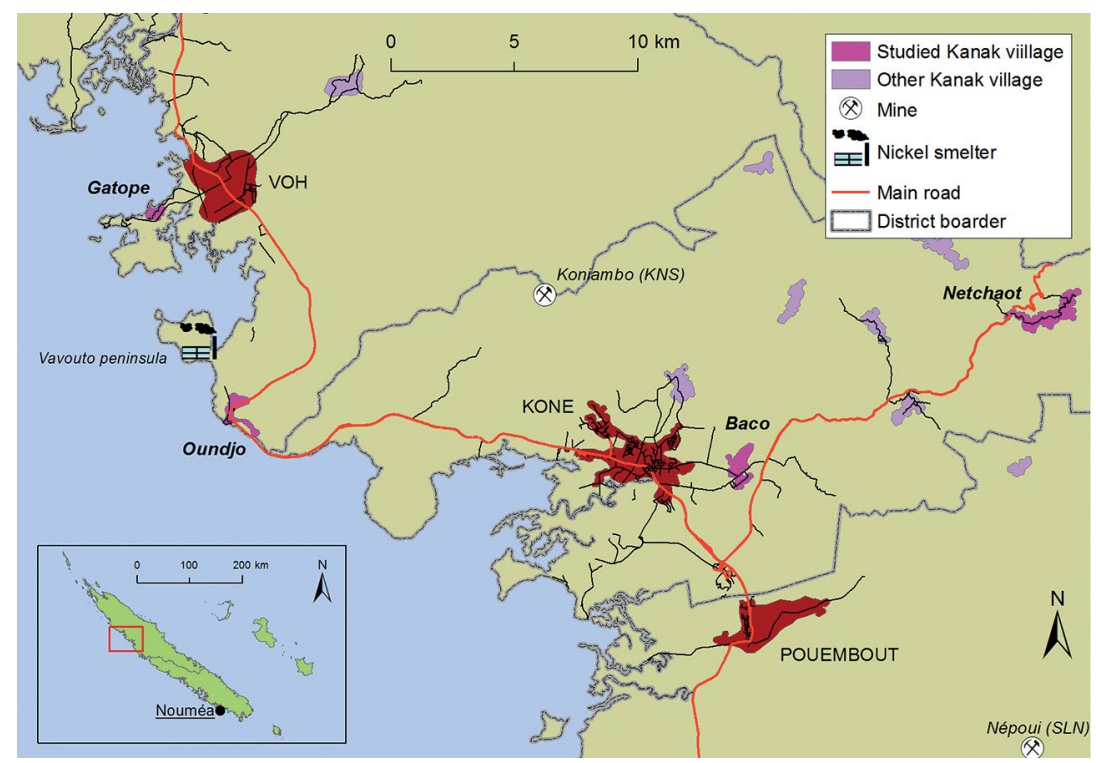

Figure 3.2 Location of the studied Kanak villages in northern New Caledonia.

Source: Author's map, based on information supplied by the Direction des Infrastructures, de la Topographie et des Transports Terrestres.

The question then is whether the researcher has to be integrated into the indigenous village for a longer period and actively participate in community life. According to Blaikie (2012), social engagement can be useful, and withdrawal into an ivory tower does not permit a deeper understanding of peoples' perceptions and opinions. My research results are based on integration into community life in the village of Baco over a period of six years.

The environment has not only a utilitarian value for Kanak societies but also a cultural heritage value. Research on environmental economics in other countries has attempted to place a monetary value on ecosystems (e.g. Constanza et al. 1997; David et al. 2007). Figure 3.3 shows a simple model to demonstrate the transformation of environmental values. 


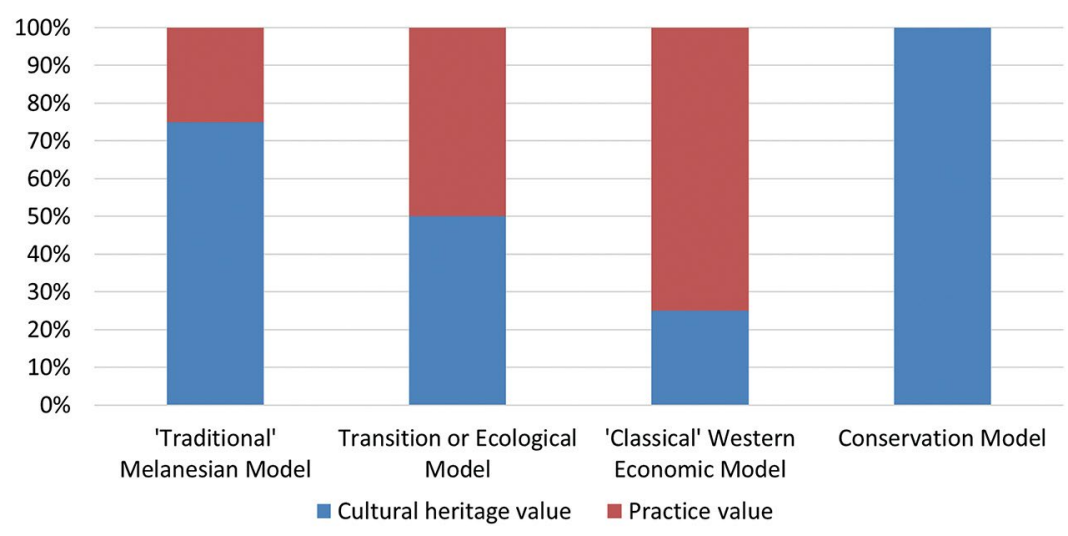

Figure 3.3 Environmental value model.

Source: Author's chart, based on personal communication from Gilbert David and Jean-Brice Herrenschmidt (2010).

Heritage values are transcribed mainly in topographical locations that represent an essential cultural reservoir. Winslow (1995: 14) notes that each clan name is a set of place names- the name of the place where the ancestor of the clan appeared and all other places that the clan occupied in its history. Ancestors are pervasive, and their presence is felt in the passage of a butterfly, in the falling rain or in the swirls of river water. The appropriation of space in a particular place results from naming and recognising the site in one's own language. The real 'owners' of a place are its founders. The specificity of the clan is primarily its history: the place and the circumstances of its appearance, the journey it undertook and the recognised symbolism of place. The social identity and legitimacy of any clan is then presented as a route or as a series of places where the group lived (Naepels 2006: 50). But Kanak property is subject to perpetual updating (Naepels 1998; Le Meur 2010; Kowasch 2012a), because the itinerary of the clan can change, and also because land can be given away. The founding group is therefore not the only one able to claim land rights. Pursuant to a 'host dynamic', the newcomer receives from the founder some ground where he can live and grow crops. It is important to note that the transfer of land represents not the transfer of ownership, but the superposition of different legitimacies: the property is not unique, but rather consists of competing titles. The founder maintains a special relationship to the land. The newcomer in turn can argue that he resided there, made exchanges with the founder and worked there, but he cannot in any way challenge the fact of having received the land of another. 
The 'traditional' Melanesian model contains a strong cultural discourse linking places to a myth and/or to a specific history. To these cultural heritage values, which include cultural practices like fishing or subsistence farming, are added economic practices, which are required for people to live and reproduce. In the transitional or ecological model, the discourse seeks to balance the importance of practical values and cultural heritage, describing a changing pattern of Melanesian lifestyle in the cash economy, or otherwise describing the evolution from a free-market economy to a sustainable development model, introducing a notion of balance between the use of the environment and its capacity to retain its heritage features. According to the classical Western economic model, the socioeconomic value of an environment is often reduced to its practical value-the economic goods and services that the environment provides. The conservation model in turn removes the question of practice by promoting the protection of natural areas perceived as part of a common heritage. Only the cultural heritage value exists in this model (see Figure 3.3).

Fishing and subsistence farming have heritage value as cultural practices, because they are used to establish or renew social relationships with other clans and to transmit cultural knowledge to younger generations in the context of customary ceremonies, as when fish are exchanged in a customary wedding ceremony. New incomes from people's involvement in the mining sector not only lead to social transformations within Kanak communities, as when farming products can be replaced by products from the supermarket, but mining projects also result in changes to landscape and territory. Fishing, hunting and farming are practised in what ToliaKelly (2006) calls 'territories of belonging'. The exploitation of mineral resources creates conflicts and negotiations over such territories.

Given that cultural heritage sites are also located on mine sites in New Caledonia, and on the customary land where the social and economic facilities required for a metallurgical plant are constructed, would it be true to say that the territories of belonging are currently being transformed by the traditional landowners themselves? Who are the actors in these development projects and what conflicts within the Kanak communities result from the projects? The territorial and social transformations linked to the Koniambo project will be analysed in the rest of this chapter. What are the implications of what Amin (2002: 397) would call this 'politics of place'? 


\section{A Short History of the Koniambo Project}

The Koniambo project has a strong symbolic value for the Kanak independence party that governs North Province. Shareholders in the project include the local company Société Minière du Sud Pacifique (SMSP), which owns 51 per cent of the shares and is owned by North Province, and the Swiss group Glencore, which holds 49 per cent. The Koniambo nickel smelter has an annual production capacity of 60,000 tonnes of ferronickel. The first pouring of nickel metal was in April 2013, and the plant was fully commissioned in November 2014. However, it failed to operate at full capacity due to technical problems and incidents.

Even before the Koniambo project went into production, North Province was reinvesting its revenues from SMSP nickel mines elsewhere in the country in wider economic development, such as tourism, aquaculture and urbanisation, along with construction of social or cultural facilities. In this case, the nickel sector is a kind of 'instrument' for economic and political independence, and not just for making profits (Winslow 1995; Pitoiset and Wéry 2008; Le Meur and Mennesson 2011; Kowasch 2012a). Investors sometimes mention 'two Koniambo projects': on one hand, the construction of the processing plant and development of the mine; on the other hand, the economic development of the Voh, Koné and Pouembout (VKP) municipalities where the Koniambo project is located.

By taking the initiative in the 1990 s to build a nickel smelter in North Province, SMSP sought an industrial partner who could provide the relevant expertise and co-financing (Néaoutyine 2006; Pitoiset and Wéry 2008). The provincial authorities and SMSP initially established a joint venture with the Canadian company Falconbridge.

SMSP contacted and negotiated with Falconbridge and then convinced the French Government-with assistance of political pressure from independence party leaders - to help it obtain the Koniambo Massif from a French mining company (Horowitz 2004: 290).

SMSP/Falconbridge won the Koniambo Massif in exchange for surrendering the licence to mine another nickel deposit (Poum), in the far north of New Caledonia, to SLN. The deal was fixed in the Bercy Agreement in 1998, signed by SMSP/Falconbridge, the French Government and the French company Eramet, which is SLN's parent company (Pitoiset and Wéry 2008). In 2006, Falconbridge was taken 
over by the Swiss mining company Xstrata, which thus became the new partner of SMSP (Pitoiset and Wéry 2008; see also Chapter 2, this volume). Xstrata has mainly financed construction of the processing plant on Vavouto Peninsula and exploitation of the nickel deposit, while SMSP holds the mining tenements in the Koniambo Massif and has support from local Kanak communities, even though nickel mining has caused widespread environmental pollution in the country for nearly 150 years. With the recent development of the Koniambo and Goro nickel projects (see Chapter 6, this volume), New Caledonia is expected to triple its nickel production and become the second-largest nickel producer in the world. In October 2012, around 6,000 workers from different countries were working (and mostly living) on the Koniambo construction site. Chinese and Filipino workers, who assembled the components of the nickel smelter and the power plant, travel the world doing such work. Direct employment on the project accounted for between 800 and 1,000 jobs once it came into production.

SMSP already possesses nickel mines in Ouaco and Poya, on the west coast, and Nakety and Kouaoua, on the east coast of Grande Terre, the main island of New Caledonia, all located in North Province. Since 1995, SMSP had become the largest ore exporting company in New Caledonia because SLN, which produces more than 50 per cent of the ores, feeds the majority of its output into its Doniambo processing plant in Nouméa. The primary goal of SMSP was always to become a 'metallurgist' and to transform nickel ores into metal. This milestone was achieved in 2008 with the start-up of a processing plant in Gwangyang in South Korea. The nickel smelter is operated by Société du Nickel de Nouvelle-Calédonie et Corée (SNNC), a joint venture between SMSP, holding 51 per cent of the shares, and its Korean partner POSCO, holding 49 per cent. SMSP and POSCO created a second joint venture, which is simply called Nickel Mining Company (in English), to exploit all of SMSP's nickel deposits in New Caledonia apart from the Koniambo deposit. The revenues from the smelter in Gwangyang were used to co-finance construction of the Koniambo plant. In both cases, the $51 / 49$ per cent model of ownership is remarkable because it has been rolled out to an overseas investor. It is little known globally that an indigenous mining company holds 51 per cent of the shares in a project that is operating in South Korea (with POSCO), as well as another joint venture planned in China, with the Chinese nickel producer Jinchuan. Processing plants are integral to both deals. 
The Koniambo project is located in a rural area where the infrastructure required for the new nickel smelter was initially lacking. In 2004, North Province set out to provide a broader development of the VKP area, which only had 8,211 inhabitants at the time (Kowasch 2012c; North Province 2013). In the five years until the next census (in 2009), the local population grew by an average of 18 per cent each year. The resident population of the provincial capital, Koné, where many of the new facilities were built, grew from 5,199 in 2009 to 7,340 in 2014 (GoNC 2016: 31). To welcome the new arrivals, the main priority of the public authorities was to provide a greater supply of rental housing. Anne Pitoiset and Claudine Wéry described the transformation in their biography Mystère Dang:

The villagers discover traffic, real estate speculation, rental housing development and the massive arrival of new peoples. The money flows and no question, this time, people don't want to be dispossessed ... For the first time, the nickel boom leaves Nouméa and its effects are felt in Kanak country. (Pitoiset and Wéry 2008: 106)

In New Caledonia, it is common to talk of the 'bush' beyond Nouméa in order to highlight the demographic and economic primacy of the capital located in South Province, 270 kilometres south of Koné. Some 40 per cent of New Caledonia's population live in Nouméa, and the capital accounts for roughly 75 per cent of formal employment. The spatial imbalance of the territory, inherited from the colonial period, has continued to widen. A policy of 'territorial rebalancing' was started with the Matignon Agreements of 1988. Horowitz (2004: 307-8) noted how:

Many people hope that the [Koniambo] project will entail an economic readjustment or 'rebalancing' (rééquilibrage) as promised in the Matignon and Nouméa Accords, allowing the Northern Province to be placed on more equal footing with the Southern Province.

The development of the VKP area is an example of this policy (Néaoutyine 2006). The provincial authorities wanted to turn the growing VKP area into a real urban centre, an Oceanic city to rival Nouméa. New rental housing, shops and industrial areas mushroomed (see Figures 3.4 and 3.5). One problem has been that the settlements and socioeconomic facilities, such as shops and schools, in the area are scattered in different locations. Access to facilities such as supermarkets requires the use of a car. Public transport does not really exist; there are only some shuttle buses operated by individual businessmen that link the Kanak villages to the 
three towns (Voh, Koné and Pouembout). The process of socioeconomic development was initially concentrated on private and state land, but the public authorities have since made efforts to integrate Kanak clans and their customary land into the process (North Province 2013).

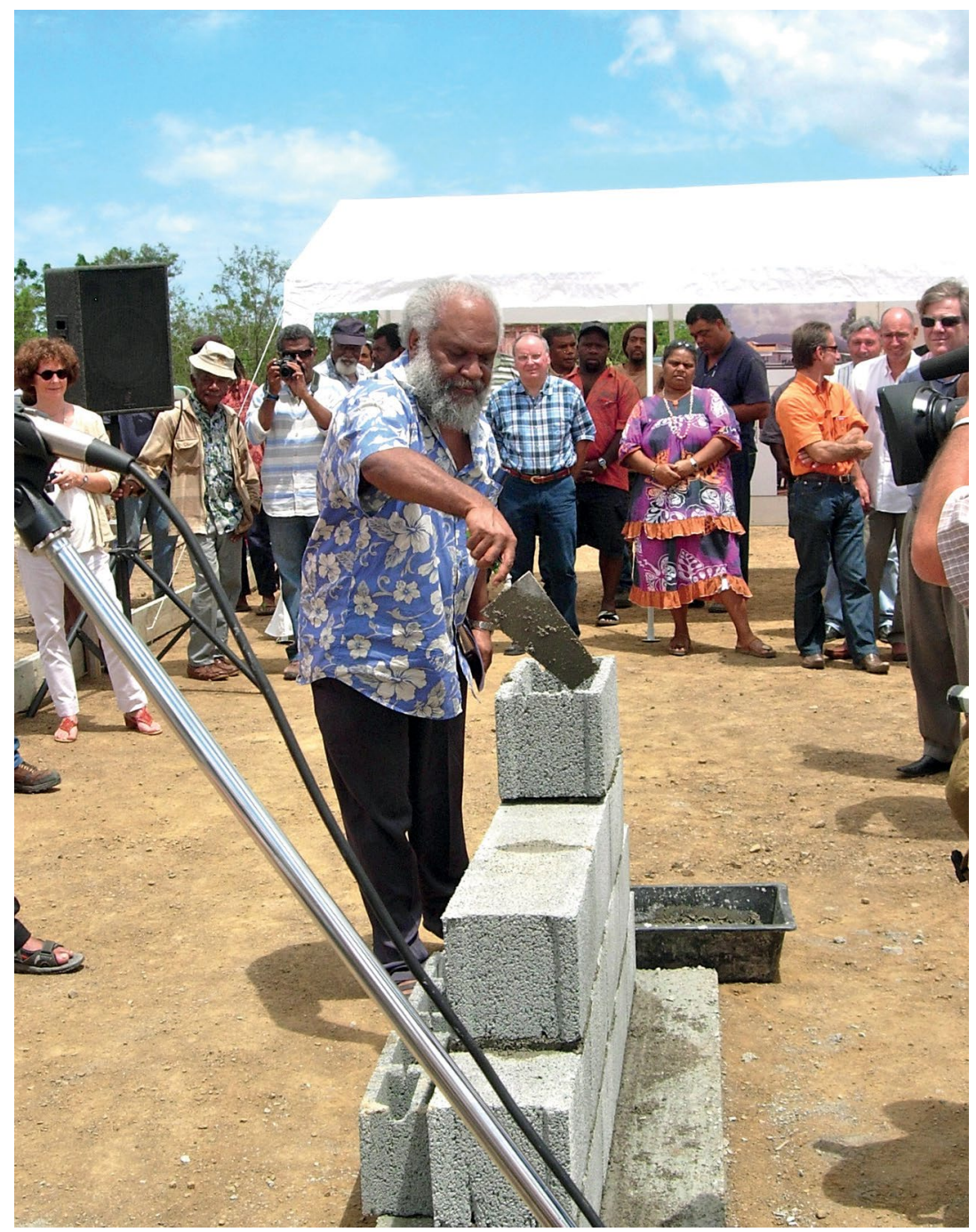

Figure 3.4 First stone of the new cultural centre in Koné, 2008.

Source: Photo by Matthias Kowasch. 


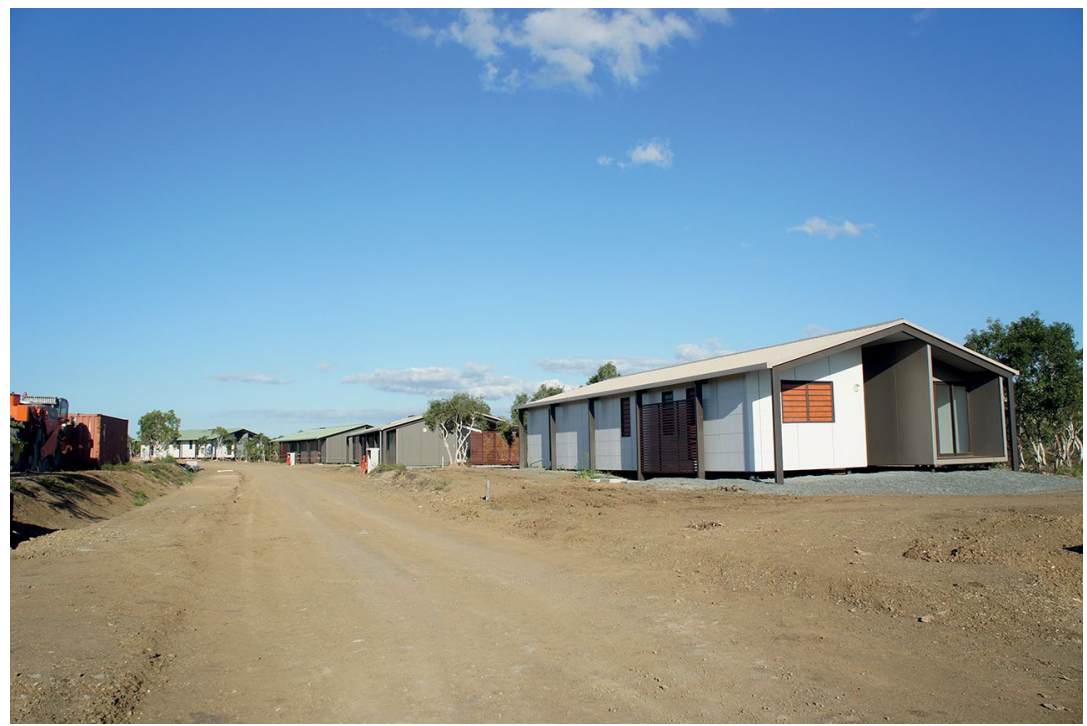

Figure 3.5 Rental housing on customary land, Baco, 2011.

Source: Photo by Matthias Kowasch.

With the construction of the nickel smelter in North Province, and a wider development of the VKP area, the independence movement has also wanted to show that Kanak people are capable of handling a major global mining project, and that the Koniambo project can indeed lead to more economic and financial independence from France. The Kanak independence leader Jean-Marie Tjibaou explained:

The future of self-determination and the promotion of dignity require that we are not beggars. For this, it is necessary that the country helps people organising themselves to produce wealth, making them financially independent. (Pitoiset and Wéry 2008: 161)

The businessman D. Xamène from Oundjo, who has a subcontracting company involved in earthworks and equipment transport, expressed the political dimension of the project as follows:

One day we will have our independence, we will have our factory ... It is the wish of all Kanak peoples. This is a political struggle. (Kowasch 2010:374)

Nevertheless, the focus on the mining industry is a bold move, because the general economic development strategy depends on nickel prices in the world market. 


\section{Employment, Business Creation and Subcontracting}

The study conducted in the four Kanak villages in the neighbourhood of the new nickel smelter showed that many of the residents of these communities supported the Koniambo project: 60 per cent of the 239 interviewed people were in favour or rather in favour of the project; only 13 per cent were against or rather against. Kanak people generally perceive the Koniambo project to be 'their project', one that is meant to generate employment and services, economic development and political emancipation. Their hopes largely hinge on the prospect of employment (198 responses). Broader economic development of the VKP area ranks second in the number of responses (87) (Kowasch 2010:373). The mining sector is mainly considered as a big employer, not as an instrument for development more broadly. The interviewees showed an interest in working either for the mining operator Koniambo Nickel SAS (KNS) or for one of its subcontracting companies. Among the 239 interviewees, aged from sixteen to seventy years, 73 (31 per cent) wanted to be employed by KNS and 26 (11 per cent) were already working for the mining company or for a subcontractor (Kowasch 2010: 454). Young people under thirty years of age especially expressed a great willingness to work in the mining industry. Most of the interviewees wanted to be truck drivers or cleaners, which is consistent with the job opportunities that actually exist for many people in the neighbouring villages. Being a truck driver or cleaner is popular because parents, grandparents and friends already have experience in these professions, and these jobs also allow people to stay in their home village. The customary and family relationships that are central to one's identity are easier to maintain if one can stay in the village. Furthermore, most of the interviewees who were motivated to work in the mining sector did not have the qualifications to apply for higher-paid positions. In many cases, it was cheaper for companies to employ Asian workers than to hire local workers, partly because foreign workers are exempt from many of the strict regulations that apply to local working conditions. For example, Chinese workers who were employed by the China Machinery Industry Construction Group could work 60 hours per week, and unofficially often worked even longer hours, and still earn the New Caledonian minimum salary, which is around US $\$ 1,400$ per month. As pointed out in Chapter 2 (this volume), local communities feared the massive influx of foreign workers because so many were single men. KNS did make an effort to employ local people, so in late 2012, at the peak of the construction 
phase, over 60 per cent of the workers on the Vavouto construction site were locals. Furthermore, 77 per cent of the local employees, excluding the expatriates, were natives of North Province, 77 per cent were Kanak, and the most common employee profile was that of the young male Kanak who was a native of North Province (see Chapter 2, this volume). This helps to explain why so many of my own interviewees were interested in working for KNS.

The education level of interviewees in the villages of Netchaot, Baco, Oundjo and Gatope who indicated that they were interested in working on the Koniambo project is shown in Figure 3.6. The majority of young Kanak people between sixteen and twenty-nine years old (55 per cent of the interviewees) had been to secondary school, but had not obtained a higher school certificate. Often, they continued with specialised training for jobs like that of technician or truck driver. Only 22 per cent had obtained a higher school certificate, and a small minority (5.5 per cent) had spent a minimum of two years on a university degree.

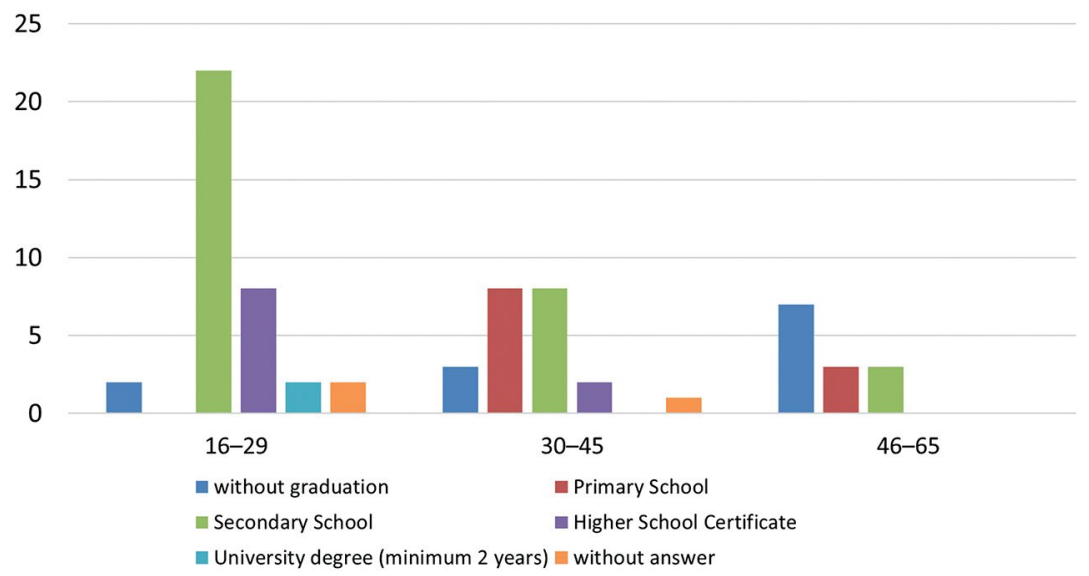

Figure 3.6 Education level of the peoples in the four villages motivated to work in the Koniambo project.

Source: Kowasch (2010: 457).

These results are consistent with those from a study conducted by the provincial Observatoire de la Santé et des Actions Sociales. That study found that just 4 per cent of young Kanaks in North Province obtained a higher school certificate, which permits one to enter university, as against 10 per cent in non-Kanak communities (North Province 2008: 26). Among interviewees aged between thirty and forty-five years, no one had completed a university degree. The majority ( 72 per cent) had finished 
their education at the end of primary school (36 per cent) or secondary school (36 per cent). In keeping with the colonial history of the country, no one between the ages of forty-six and sixty-five years in the four studied villages held either a higher school certificate or university degree. This study also showed that young Kanaks had lower annual wages than their European fellow citizens with the same skills: 'We have to note that the young Kanaks who work have an income less than half than all other communities: US\$8,677 against US\$19,500' (ibid.: 18). The study also took the example of businessmen and noted that non-Kanaks earned three times more than Kanaks (US\$30,136 against US\$10,665).

In their working document, Le Meur et al. (2012: 16-20) explain that Kanak business development started late, but accelerated with the construction of two new nickel smelters in the north and south of New Caledonia. During the first nickel boom (1967-71), the creation of small and medium enterprises did not involve the Kanak population, but was dominated by new immigrants (ibid.: 16). In 1993, Isabelle Leblic (1993: 240-51) reported a growing demand for subcontracting in the mining sector in North Province. Kanak subcontracting in the mining sector finally accelerated with the construction of the Goro and Koniambo smelters at the beginning of the new millennium.

In North Province, there were more than 550 registered companies by 2008, compared with 340 in 2005 and less than 300 in 1995 (North Province 2013: 35). Even if not all newly established companies were subcontractors in the Koniambo project, the increase in business activity was still a consequence of the development of the nickel sector. From 1998 to 2009 , nearly 90 subcontracting companies were founded to service the Koniambo project, most of them with the support of KNS (Le Meur et al. 2012). Examples of subcontractors created with such support are Société des Travaux du Massif Koniambo (STMK) and Société Webuihoone Maritime SAS (SOWEMAR) (ibid.: 45). ${ }^{2}$ The main activity of SOWEMAR was maritime transport, which included the renting of two tug boats in order to bring container ships from the lagoon entrance to the port of Vavouto (Kowasch 2012a, 2012b). It was also responsible for security around the plant site, and had a role to play in the marine emergency plans of KNS, such as intervening in the event of accidental pollution.

2 Shares in SOWEMAR were split between a clan company from Gatope (46 per cent), a collection of coastal clans (5 per cent), and SOFINOR, an SMSP subsidiary ( 49 per cent) (see Chapter 2, this volume; also Kowasch 2010). 
KNS also assisted in the foundation of SAS Vavouto, which is a federation of various local companies and businessmen (see Chapter 2, this volume). It was founded in 2008 as the interface between local subcontractors and the mining company. The goal of SAS Vavouto was to seek, manage and distribute contracts by dividing them into several subcontracts for its members. Indeed, in accordance with its development strategy, North Province does not allow royalty payments to Kanak communities but instead supports their direct participation in the Koniambo project by means of business contracts and employment. Not all local subcontractors are members of SAS Vavouto but, as of August 2012, ${ }^{3}$ the company had federated 126 mostly local (often indigenous) enterprises (personal communication, SAS Vavouto, August 2012). Voh, where the smelter was built, had the highest concentration of subcontractors- 54 enterprises (see Figure 3.7).

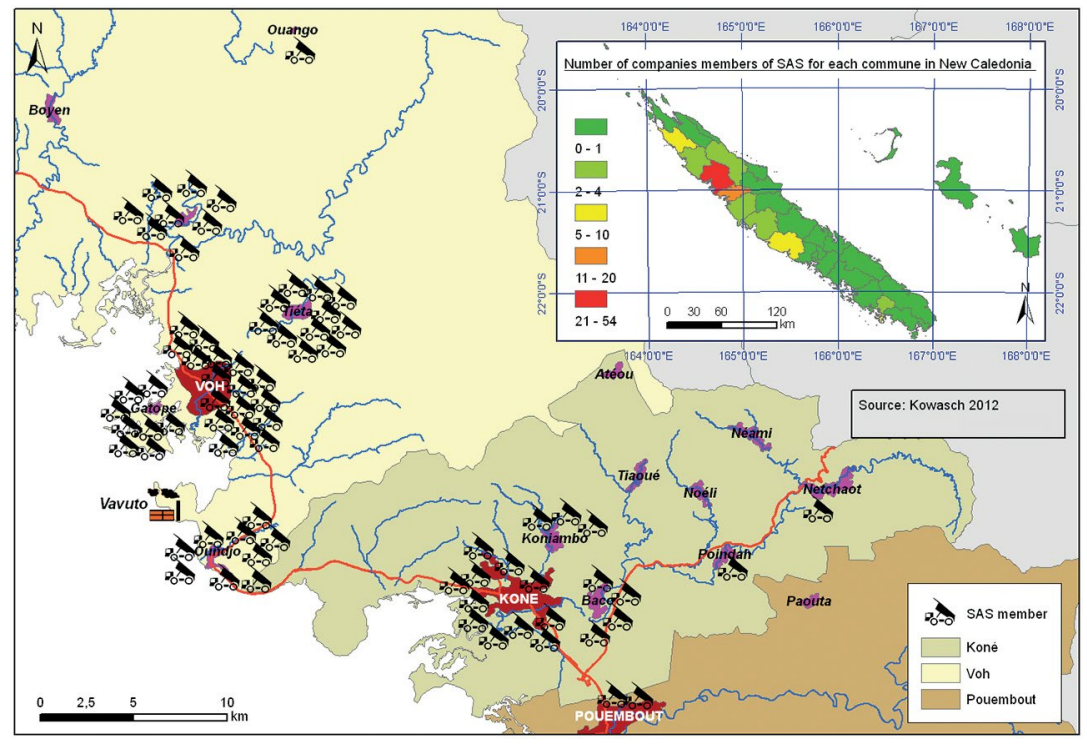

Figure 3.7 Subcontracting companies belonging to SAS Vavouto in August 2012.

Source: Author's map, based on information supplied by the Bureau des Entreprises du Nord.

3 Around 6,000 people were working on the Vavouto construction site at the peak of the construction phase. 
Of the 126 enterprises belonging to SAS Vavouto at the time, nine were from Oundjo, eight from Gatope, two from Baco, and one from Netchaot. The further the village from the nickel smelter site, the fewer the number of SAS Vavouto members. People living closer to the construction site felt more involved and were better informed about job and business creation opportunities. Furthermore, KNS gave more support to business creation in the neighbourhood of the project, which meant that business creation and local employment were both higher in the neighbouring villages of Oundjo and Gatope than in Netchaot, which is more than 30 kilometres from Vavouto Peninsula.

Most Kanak subcontractors were involved in three types of business: earthworks and the transportation of material and personnel. The business types of all small enterprises located in Baco and Oundjo were identified in the revision of the regional planning and development program for the VKPP area (VKP and the commune of Poya) in 2012 (North Province 2013). The types of business operating in Baco are shown in Figure 3.8 (though not all of them were subcontractors in the Koniambo project).

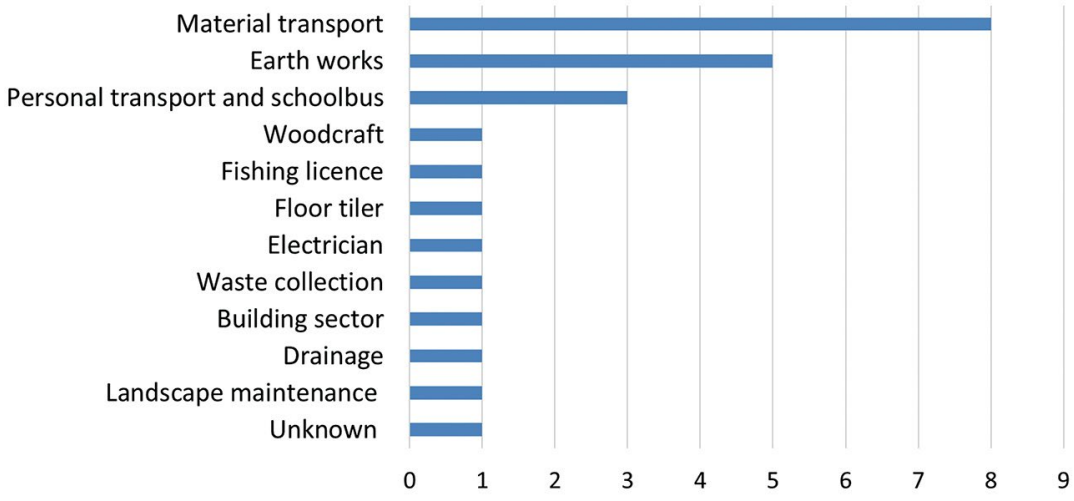

Figure 3.8 Number of enterprises per working area in Baco, August 2012.

Sources: Kowasch (2010), North Province (2013). 


\section{Customary Land Claims, Sacred Places and Economic Projects}

During French colonisation, the indigenous Kanaks were driven into reservations, just like the indigenous populations of North America. The reservations occupied about 10 per cent of Grande Terre. Land reform in New Caledonia started in 1978 with a view to buying land from settlers and returning it to the Kanak clans. Kanak clans create local associations in order to claim and receive these estates. In 2010, the results seemed to be satisfactory to the Agence de Développement Rural et d'Aménagement Foncier (ADRAF), because a balance of landownership had been achieved: customary land and European private estates both occupied 295,300 hectares (Kowasch 2012a: 206). Some 63 per cent of the surface area was classified as state land, while 1 per cent remained subject to negotiation by ADRAF. As a result, Kanak clans theoretically have the opportunity to establish economic projects on their land. ADRAF attributes estates to local associations licensed to do business. These associations are known as 'local groups with special rights', groupements de droit particulier local (GDPLs), rather like Aboriginal corporations in Australia. But, until now, much of the redistributed land has been left fallow because the primary motivation of the clans is usually not economic (Doumenge 2003). The allocations are generally based on clan histories and identity values. The anthropologist Michel Naepels (2006: 50) notes that the 'social identity and legitimacy of any group is an itinerary, a series of places where the group passed'. From the Kanak viewpoint, the legitimacy of land claims results from the places where the clan has lived during its history. The 'first occupants' have given a name in their language to those places. But the land can be given to another clan for farming or house building, so different legitimacies can overlap. The legitimacy of land claims becomes negotiable, characterised as a 'game of power and influence' (Le Meur 2010: 109). Moreover, the displacement of clans during colonisation now makes it difficult to say who the 'first occupant' was.

This historical context has led to land conflicts that restrain potential investment. Another handicap for investors is the fact that customary land is inalienable and non-transferable, so investors sign a 'customary deed' with the traditional landowners, which gives them some security of tenure, but which can theoretically be removed at any time. In the absence of a legal framework, the Kanak-dominated North Province 
supports and provides economic projects on customary land. That is why the initiative for projects on customary land generally comes from the public authorities, not from Kanak clans. Project implementation rests in the hands of state actors, so the involvement of customary representatives can be described as 'guided participation' in socioeconomic development.

As already mentioned, the provincial authorities have encouraged neighbouring Kanak communities to participate in the Koniambo project. The VKP area, including its customary land, should be turned into an urban centre, so the public authorities have made efforts to integrate Kanak clans and their customary land into the process of urban development. It is the larger tracts of customary land that are more likely to be the target for potential economic projects. In South Province, in the neighbourhood of the Goro nickel project, customary land is confined to a narrow coastal zone, and development of this land for new sociocultural facilities or industrial parks is almost precluded. In the north, the proportion of customary land is significantly higher. Around 50 per cent of the district of Koné, 28 per cent of Voh, and 12 per cent of Pouembout is classified as 'customary land' (ADRAF 2012: 5) (see Figure 3.9). Land reform has resulted in the doubling of the amount of customary land in the district of Koné over a period of 25 years, from 9,820 hectares in 1978 to 18,720 hectares in 2004 (ADRAF 2004: 6). When we compare the four villages of Gatope, Oundjo, Baco and Netchaot, the situation of Baco, whose territory is cut lengthwise by the north-south Territorial Road No. 1 and also by the road connecting the east and west coasts, is particularly interesting (North Province 2013: 43). The customary estate of Baco covers a total area of 4,264 hectares-229 hectares in the tribal reservation and 4,035 hectares transferred to customary ownership. In the village of Baco, the clans are grouped into four 'broader clans': Baco, Poavidapthia, Poaxu and Wabealo. Each of these broader clans has its own local association (GDPL) to manage its customary land. Thanks to its geographical location between the towns of Pouembout and Koné, in front of the parliament house of North Province, Baco is ideally positioned for development projects. 


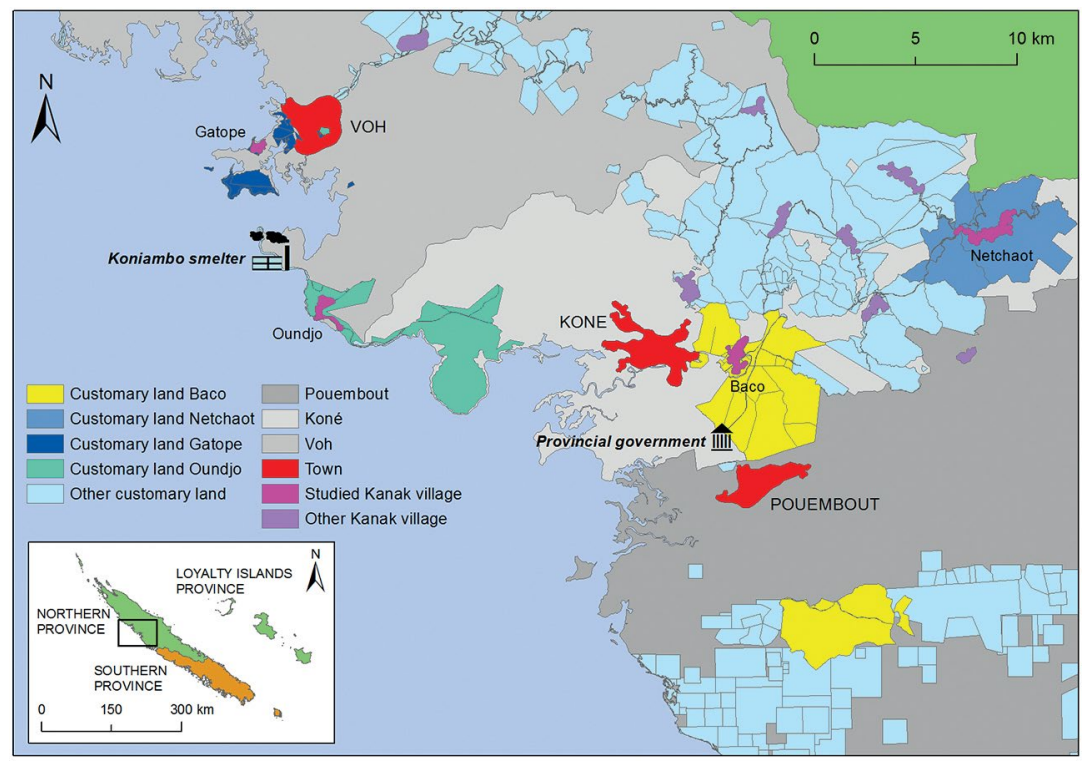

Figure 3.9 Size of customary lands of the villages of Netchaot, Baco, Oundjo and Gatope.

Source: Author's map, based on information supplied by the Direction des Infrastructures, de la Topographie et des Transports Terrestres and the Agence de Développement Rural et d'Aménagement Foncier.

One example is the development project on the customary land of the Baco GDPL (517 hectares). The provincial authorities approached the customary representatives in order to create sociocultural and economic facilities such as rental housing, a commercial centre, a bank, a cinema, an art school, a Lapita (pottery) museum, a bus terminal and an area for shops and industrial services on a total area of 48 hectares. Construction started in August 2010 and the first 15 houses were occupied in 2012. The Baco association then embarked on a second economic project: the establishment of a 17-hectare industrial park. This time, the project was supported by the council of elders representing all the clans living in Baco because the park was to be built on the village's customary reservation, next to Koné-Tiwaka, the connecting road between the east and west coast of New Caledonia. The first stone for the new industrial park, that would host only non-polluting industries and crafts, was laid in February 2009. The goal of both projects was to develop local employment and to benefit from the broader development of the VKP area. Baco has often been described as a 'flagship project' for development on customary land in New Caledonia. 
Other Kanak villages do not have the same advantages. Netchaot has spacious estates, but the village is more than 30 kilometres from the construction site and around 15 kilometres from the provincial capital at Koné. Gatope's customary land is close to the nickel smelter but is limited in extent-286 hectares in the tribal reservation and only 32 hectares that has been added by redistribution-but this latter area did become the site of newly built rental housing. Oundjo has a large area of customary land that is located between the town of Koné and the nickel smelter. Originally, the mining operator SMSP wanted to build its processing plant on Pinjen Peninsula (1,610 hectares), which is owned by the clans living in Oundjo. In 1999, SMSP organised a meeting in Oundjo to officially ask for permission to do this.

The peninsula had several advantages for this purpose. It was located near the town of Koné, it had good road access, because Territorial Road No. 1 passes just behind the peninsula, and it was also accessible by boat at different points. In addition, the terrain was flat, which would make it easier to construct the smelter, and since it was located between two entrances to a single lagoon, container ships could enter the lagoon through one passage and leave through the other.

However, the clans did not agree on the proposal, which led to the socalled 'Pinjen conflict' (Horowitz 2003a, 2003b; Kowasch 2010, 2012a, $2012 \mathrm{~b}$ ). While some of the clans argued in favour of the financial benefits of land leasing, others were opposed because the peninsula contains sacred places, where ancestors reside, and was used for hunting and crab fishing. In addition, Pinjen had become a symbol of Kanak struggles for land and cultural recognition, having been transferred to the clans in the 1980s after several claims and contests, so those opposing the new development proposal did not want to 'lose' this land for a second time. In the end, the majority of the clans voted against leasing the land to SMSP, so the company bought a site further north, on Vavouto Peninsula.

Meanwhile, the conflict between the clans in Oundjo continued, but we have to note that this was not just a 'mining conflict'. Pinjen Peninsula has a long history of settlement, colonisation and expulsion (Kowasch 2012b: 205). Several families from clans now living in Oundjo, Gatope and Népou ${ }^{4}$ passed through Pinjen at one time in their clan itinerary. The legitimacy of land claims in Pinjen is still a subject of struggle, even

4 A Kanak village in the commune of Poya, in the south of Pouembout. 
if ADRAF attributed the peninsula to an association including all the clans from Oundjo in 1989. The suggestion that every current 'mining conflict' is not only about resources and benefits, because it has a longer history, fits well with the observations of the geographer Glenn Banks, who argued that:

conflicts are never finally 'resolved' ... current conflicts are likely to form the background to future conflicts, even when it appears that the parties have 'settled' their differences (Banks 2008: 26).

Development projects on customary land are generally implemented outside of local people's actual living space. A majority of the Kanak people do not want the urban transformation of the VKP area to affect their own villages. The maintenance of traditions and community values is very important. As the businessman D. Xamène explained, Kanak people know that their lifestyles will change under Western influence, but this does not mean that all Kanak people will support the change (Kowasch 2010: 460). At the same time, it is important to note the lack of space available for development projects inside the Kanak villages. The tribal reservations are the bitter fruit of colonial land dispossession and displacement. From the end of the nineteenth to the mid-twentieth century, they represented a restricted space for the Kanak population. Land reform involved a strategy of demographic de-concentration, and the 'reconquest' of land in favour of Kanak clans. In the current logic of negotiated decolonisation, development projects on customary land outside the villages represent a reappropriation of this land.

\section{Conflicts and Social Transformations}

The extent of local people's approval of the Koniambo project seems to decrease with their proximity to the site of the new nickel smelter (Figure 3.10). In Oundjo, only 2 kilometres from Vavouto, 28 per cent of the interviewees were against or rather against the project. In Gatope (12 kilometres away), 24 per cent gave these responses; in Baco (around 15 kilometres away), the figure was 12 per cent; and in Netchaot (30 kilometres away) it was 2 per cent. 


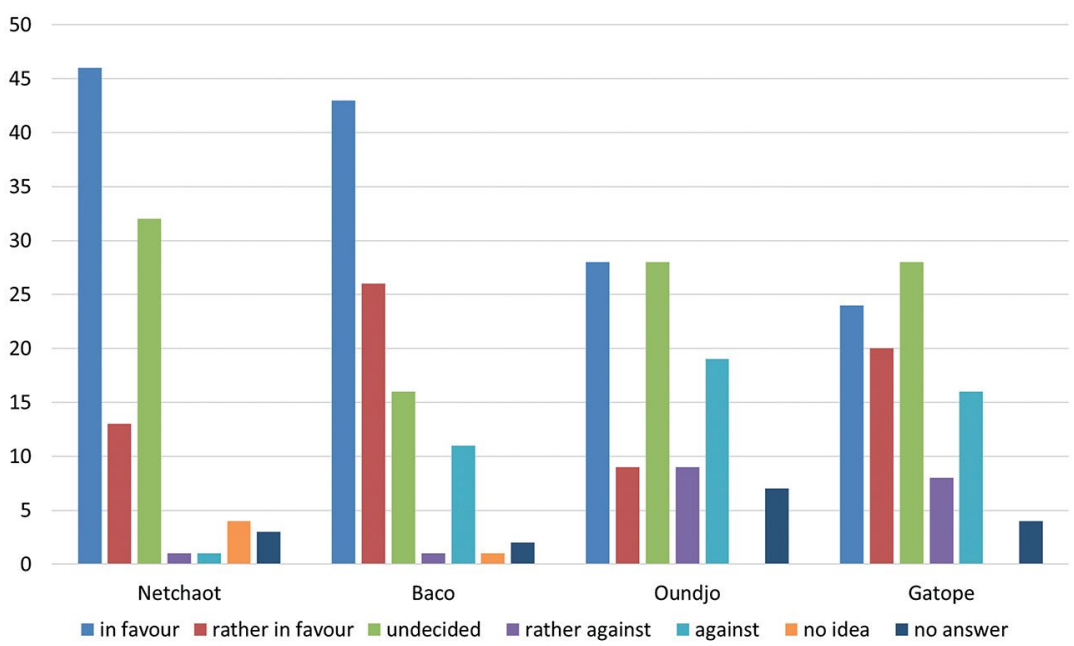

Figure 3.10 Difference in perceptions of the four neighbouring Kanak villages vis-à-vis the Koniambo project (per cent per village).

Source: Kowasch (2010: 367).

Gatope and Oundjo are the two villages that have experienced the greatest environmental impacts. These included the destruction of the mangroves where crabs were hunted. Foreign construction workers who spent their free time on the beach at Gatope or on the coast near Oundjo made disruptive noises and left waste behind. Furthermore, the Chinese and Filipinos did not speak French, so could not communicate with local people, while the latter did not seem very interested in meeting the foreign workers in any case. Residents of Gatope helped to dig the access channel from the port of Vavouto to the open sea, while fishermen from Oundjo saw the container ships arriving and leaving every day. Furthermore, the territorial road bisects the village of Oundjo, and the trucks transporting equipment to the building site damaged the road and made it dangerous for children to cross.

The participation of local Kanak people in the Koniambo project has also depended on the level of social cohesion and solidarity within the clan and the village. As we have seen, development projects on customary land represent one way to benefit from the project. The establishment of sociocultural and economic facilities on customary land is not just a matter of interest to the individual businessman, but also to the clan or even the whole village. This 'collective business participation' requires group consensus. Where there has been disagreement, the project has not moved forward. There are several examples of projects that were put on 
hold, including a large rental housing project in the village of Koniambo and the establishment of facilities on the customary land of the Wabealo GDPL in Baco.

When they use the natural environment, or reclaimed land, to participate in the economic development of the VKP area, Kanak communities transform the value of the land itself. Sacred places lose their value when replaced by a rental housing project. Mineral extraction can destroy sacred places with strong cultural heritage value. The values of other sacred places increase, because clans want to preserve them for traditional activities or to respect the ancestors and or maintain their identity value. Traditional landowners want to benefit from mining activities when they make customary land available to foreign and local companies. To be members of the 'contact clan' for public authorities or the mining company is a kind of recognition of their status as 'landowners'. As we have already seen, customary land is characterised by the superposition of different legitimacies: the property is not unique or exclusive, but rather consists of competing titles and claims. Every development on customary land entails a remodelling of the territory, which often leads to land disputes (Kowasch 2012a). But the expansion of a group's prestige and influence can be realised only in consensual manner, not just through remodelling its territory (Herrenschmidt 2003: 322). Progress that is disconnected from the land, such as employment in the nickel sector, will not lead to a change of identity or a growing influence for the clan. It is the recognition of a clan at a certain place that can change the perception of what causes territorial remodelling. Land claims are part of this game of influence and power.

Nevertheless, the growth of mining benefits, participation and material wealth in the VKP area are not enough to establish harmony and peace. Horowitz (2004: 309-10) emphasises this aspect:

History has shown, for New Caledonia as for elsewhere in Melanesia, that the generation of economic benefits is not a sufficient condition for harmony, either within the nation at large or within small-scale communities.

Everywhere in the area, the distribution of benefits and contracts has become a source of conflict. Since not everyone can have a contract or a job, socioeconomic disparities within the clans and communities neighbouring the project have increased as the mining revenues have filtered down. New inequalities are visible within these communities as 
the 'new wealthy' invest in consumer items, including cars and electronic goods. This imbalance has generated conflicts and jealousies because some Kanaks have become businessmen and have accumulated personal wealth. The problem is not always a lack of benefits to other clan members, but rather that people are not following traditional norms in terms of the distribution of such benefits. In Oundjo and Gatope, for example, social conflicts contributed to an increase in the number of purely individual businesses, and thus to 'favouring individualism' (see Chapter 2, this volume). Growing disparities within Kanak communities reflect the theory of fragmented development (Scholz 2002), in which social and regional disparities widen with the decline of social consensus and solidarity in the context of globalisation and societal fragmentation. The president of the council of elders in Oundjo spoke in July 2009 about development and business creation in his village, saying: 'Today, I say: If you want to do something, just do it! But keep it to yourself' (Kowasch 2010: 344). Greater individualism increasingly erodes traditional community life. The Pinjen conflict is still present in Oundjo, and the clans who were in favour of construction of the smelter on Pinjen Peninsula still seem to be more involved in the project. Most initiatives to create businesses are taken individually, just like the decision to apply for a job, not only in Oundjo but also in other Kanak villages. Development projects on customary land, however, are still based on collective decision making and support.

In comparison to Oundjo and Gatope, Netchaot is further from the mining site and more remote. The council of elders that meets regularly is dynamic and engaged. The customary district of Baco/Poindah, where the villages of Baco and Netchaot are located, founded a subcontracting company in order to derive a collective benefit from the Koniambo project. However, some development projects, such as the construction of rental housing for construction or mining workers, could not be implemented because Netchaot is too remote. Traditions and customary ceremonies have been preserved, with over 100 toponymic places in the village territory proving the vitality of its traditions, and the Kanak languages Paicï and Cemuhi still being spoken in the village.

The participation of Kanak people in the Koniambo project can be qualified as 'fractional' because traditional activities, including fishing, hunting and subsistence farming, are still practised. Ninety-two per cent of interviewees in the four villages who were employed had businesses were still engaged in subsistence farming of crops like yam, taro, mango, papaya and banana. Fifty-seven per cent fished in the rivers and 48 per cent went 
hunting. There are no rivers in the coastal villages of Gatope and Oundjo, where most of the residents instead fish at sea. According to large surveys conducted by the Institut Agronomique Neo-Calédonien (Guyard et al. 2013), 'multi-activity' is a characteristic of all residents in the studied villages, but employees and businessmen naturally have less time to work on farming, fishing and hunting. Sometimes they even have to buy yams for customary ceremonies. The disjunction between traditional activities and salaried employment reflects the transformation of Kanak communities in the neighbourhood of the mining project and can be a source of conflict, because the planting of yams has an identity value.

A similar situation in Papua New Guinea was described by Benedict Imbun (2011: 51-5), who wrote of the ambivalent attitude of communities near the Porgera gold mine confronted with salaried employment, business creation and wealth accumulation. Their ambivalence resulted from the juxtaposition of the status of traditional 'landowner' with the social class status generated by the mining industry. In this instance, they developed an anti-risk strategy by combining business creation with employment.

The disjunction between traditional activities and employment concerns not only farming, fishing, hunting and customary ceremonies; it also affects daily activities such as the care of children and older people. There are not enough nurseries and retirement homes in the VKP area, and this has constituted a new challenge for the local communities.

\section{Conclusion}

Historically, indigenous Kanak peoples were largely excluded from employment in the mining industry in New Caledonia. Mining employment has been the principal aspiration of Kanak people from the villages neighbouring the Koniambo project. The surveys showed that the majority of the Kanak communities support a project they consider to be 'their project', that will provide local employment but also bring broader development. For the political authorities of North Province, the mining industry is an instrument for economic independence and political emancipation. The public authorities are struggling to push the urbanisation of the VKP area where the four studied villages are located. Furthermore, the provincial authorities and SMSP have begun applying a 51/49 per cent shareholding split with multinational companies in other countries, an arrangement that is unique to New Caledonia and 
uncommon for indigenous mining companies worldwide. Their aim is to be 'masters of the exploitation of mineral resources' so as to take responsibility for wider economic development.

Meanwhile, we have to distinguish between the perceptions of mining among Kanak village people and Kanak political leaders, even if the latter also live in the villages. Sometimes, members of the provincial assembly are at the same time customary chiefs or members of the local council of elders, but in each role they have to defend other interests. Nevertheless, the public authorities have encourage the tribal populations to participate in the development process, whether through employment or through the establishment of rental housing or other sociocultural and economic facilities on customary. The construction of such facilities brings more financial benefits for the next generation because the traditional landowners must first amortise their bank loans. Collective participation in such ventures also depends on consensus, social cohesion and solidarity within the clan and the village.

But development and new socioeconomic disparities coexist. Not everybody can work in the mining sector, and not every businessman can get a contract. The struggle for contracts and employment in the mining sector is very strong, as local subcontractors have to compete with international companies and more experienced businessmen from Nouméa. Individual business creation has grown in the neighbourhood of the Koniambo project, while collective participation is often hindered by internal discord and problems with the distribution of benefits. When individual businessmen are obliged to manage 'collective enterprises', this can result in favouritism because they occupy several positions. Employment and business creation require specific professional skills and qualifications. The improvement of educational opportunities remains a challenge for North Province. Kanak people who moved to Nouméa several years ago have returned to the villages in order to benefit from the nickel boom in the north. Most of the conflicts in the villages concern the distribution of mining benefits, land claims and legitimacy. The unequal distribution of benefits can create jealousy within the communities and lead to intra- and inter-clan conflicts. Customary 'ownership' of estates leads to a flow of financial benefits, so that land claims increase when public authorities or private businessmen are planning economic projects on these estates. However, this chapter has also shown how the conflict over Pinjen Peninsula has its own history deriving from colonisation, 
displacement and customary struggles between families. The request by SMSP to build the nickel smelter on the peninsula simply 'awoke' an existing conflict whose resolution will take a long time.

Socioeconomic disparities within the indigenous community will increase in northern New Caledonia, and social differentiation and marginalisation will create new problems. But the development of the mining industry also enables new opportunities for marginalised peoples in remote villages. Employment, business creation and the establishment of rental housing and facilities generate revenues and wealth. At the same time, Kanak people continue to practise traditional activities such as subsistence farming, hunting and fishing, even when they have a regular income.

The environmental value of the estates where economic projects are implemented is changing. In terms of the environmental value model (Figure 3.3), the territorial perception of the Kanak population is moving away from the 'traditional' Melanesian model in which the cultural heritage value is considerably higher than the practical value. Greater involvement in the formal economy explains the loss of value of certain sacred places and their cultural heritage value. Young people who are working no longer have the time to care about such things, and are less interested in 'traditional' knowledge. The cultural heritage value of land is impaired by the loss of this historical or mythical knowledge (Kowasch 2012a: 203), as local perceptions are transformed into a transitional or ecological model.

The Caledonian journalist and filmmaker Anne Pitoiset describes the role of the Koniambo project and the resulting societal transformations in an interview for the journal Hebdo:

For the pro-independence movement, the step towards independence is engaged for a long time, the plant is a financial instrument and also a symbol of their ability to fit into the economy. For the non-independence parties, the project represents a key factor for the maintenance of civil peace ... But as Ian Pearce, the president of Xstrata says, the problems will really start with the beginning of production [of nickel metal]. The neighbours will see the factory fumes, they will experience increased traffic, their lives will be transformed in a way they struggle to imagine today. (Pitoiset 2013)

In early 2013, at the moment of the first pouring of nickel metal and one year before reaching full production capacity, the life of the communities was already changing. A new shopping centre had recently opened, the 
first traffic lights in Koné would soon be in service, more clan members had salaried positions, rental yields from houses and apartments were increasing, four-wheel drive vehicles could be seen everywhere in the Kanak villages, and customary weddings were being held on weekends or during holidays in order to avoid working hours. Traditional knowledge and language skills should be preserved, but work and a regular salary seem to have a growing importance for most Kanak people nowadays.

\section{References}

ADRAF (Agence de Développement Rural et d'Aménagement Foncier), 2004. 'Etat des Lieux des Terres de GDPL.' Koné: ADRAF.

—_, 2012. 'Etude Foncière Voh-Koné-Pouembout-Poya. Partie 1: La Situation Foncière.' Nouméa: ADRAF.

Amin, A., 2002. 'Ethnicity and the Multicultural City: Living with Diversity.' Environment and Planning A34: 959-980. doi.org/10.1068/ a3537

Auty, R.M., 1993. Sustaining Development in Mineral Economies: The Resource Curse Thesis. London: Routledge.

Banks, G., 1996. 'Compensation for Mining: Benefit or Time-Bomb? The Porgera Gold Mine.' In R. Howitt with J. Connell and P. Hirsch (eds), Resources, Nations and Indigenous Peoples: Case Studies from Australasia, Melanesia and Southeast Asia. Melbourne: Oxford University Press.

__, 2008. 'Understanding "Resource" Conflicts in Papua New Guinea.' Asia Pacific Viewpoint 49: 23-34. doi.org/10.1111/j.14678373.2008.00358.x

Bebbington, A., L. Hinojosa, D. Humphreys-Bebbington, M.L. Burneo and X. Warnaars, 2009. 'Contention and Ambiguity: Mining and the Possibilities of Development.' Development and Change 39: 887-914. doi.org/10.1111/j.1467-7660.2008.00517.x

Blaikie, P., 2012. 'Should Some Political Ecology Be Useful? The Inaugural Lecture for the Cultural and Political Ecology Specialty Group, Annual Meeting of the Association of American Geographers, April 2010.' Geoforum 43: 231-239. doi.org/10.1016/j.geoforum.2011.08.010 
Constanza, R., R. D’Arge, R. De Groot, S. Farber, M. Grasso, B. Hanonnon, K. Limburg, S. Naeem, R. O’Neill, J. Paruelo, R.G. Raskin and P. Sutton, 1997. 'The Value of the World's Ecosystem Services and Natural Capital.' Nature 387: 253-260. doi.org/10.1038/387253a0

David, G., J.-B. Herrenschmidt and E. Mirault, 2007. Valeur Sociale et Économique des Récifs Coralliens du Pacifique Insulaire. Nouméa: South Pacific Commission, Coral Reef Initiatives for the Pacific.

Demmer, C., 2007. 'Autochtonie, Nickel et Environnement en Nouvelle-Calédonie: Une Nouvelle Stratégie Kanake.' Vacarme 39: 43-48. doi.org/10.3917/vaca.039.0043

Doumenge, F., 2003. 'La France Confrontée au Trou Noir du Pacifique, la Face Inconnue de la Question Calédonienne.' Conflits Actuels: Revue d'Étude Politique 10: 101-112.

Emergences, 2009a. 'Baco-Approche des Dynamiques sur l'Espace Coutumier.' Koné: Document du dossier (Diagnostic-Actions des Terres Coutumières de Koné-Pouembout)/Volet Tribu/GDPL.

—_ 2009b. 'Netchaot-Approche des Dynamiques sur l'Espace Coutumier.' Koné: Document du dossier (Diagnostic_Actions des Terres Coutumières de Koné-Pouembout)/Volet Tribu/GDPL.

Freudenburg, W. and L. Wilson, 2002. 'Mining the Data: Analysing the Economic Implications of Mining for Nonmetropolitan Regions.' Sociological Inquiry 73: 549-575. doi.org/10.1111/1475-682X.00034

GoNC (Government of New Caledonia), 2016. 'Tableau de l'Économie Calédonienne (TEC).' Nouméa: Institut de la Statistique et des Études Économiques.

Graff, S., 2012. 'Quand Combat et Revendications Kanak ou Politique de l'Etat Français Manient Indépendance, Décolonisation, Autodétermination et Autochtonie en Nouvelle-Calédonie.' Journal de la Société des Océanistes 134: 61-83. doi.org/10.4000/jso.6647

Grochain S. and D. Poithily, 2011. 'Sous-traitance Minière en NouvelleCalédonie, le Projet Koniambo.' Nouméa: CNRT Nickel (Document de Travail 4, Gouvernance Minière). 
Guyard S., L. Apithy, S. Bouard, J.-M. Sourisseau, M. Passouant, P.M. Bosc and J.-F. Bélières, 2013. L'Agriculture des Tribus en NouvelleCalédonie : Résultats d'une Enquête de 2010 sur la Place et les Fonctions de l'Agriculture, l'Élevage, la Pêche et la Chasse pour les Groupes Domestiques Résident en Tribu. Koné: Institut Agronomique NéoCalédonien/Centre de Coopération Internationale pour la Recherche Agronomique pour le Développement.

Herrenschmidt, J.-B., 2003. 'Territorialité et Identités en Mélanésie.' In D. Guillaud, C. Huetz de Lemps and O. Sevin (eds), Îles Rêvées Territoires et Identités en Crise dans le Pacifique Insulaire. Paris: Presses de l'Université de Paris-Sorbonne/Institut de Recherche pour le Développement.

Horowitz, L.S., 2003a. Stranger in One's Own Home: A Micropolitical Analysis of the Engagements of Kanak Villagers with a Multinational Mining Project in New Caledonia. Canberra: The Australian National University ( $\mathrm{PhD}$ thesis).

___, 2003b. 'La Micropolitique de la Mine en Nouvelle-Calédonie: Analyse des Conflits Autour d'un Projet Minier au Sein d'une Communauté Kanak.' Journal de la Société des Océanistes 117: 255271.

—_, 2004. 'Toward a Viable Independence? The Koniambo Project and the Political Economy of Mining in New Caledonia.' The Contemporary Pacific 16: 287-319. doi.org/10.1353/cp.2004.0047

Imbun, B., 2011. Anthropology of Mining in Papua New Guinea Greenfields. New York: Nova Publishers.

Kowasch, M., 2010. Les Populations Kanak Face au Développement de l'Industrie du Nickel en Nouvelle-Calédonie. Université Montpellier III/Université de Heidelberg (PhD thesis).

—_, 2012a. 'Le Développement de l'Industrie du Nickel et la Transformation de la Valeur Environnementale en NouvelleCalédonie.' Journal of Political Ecology 19: 202-220.

__ 2012b. 'Les Lieux Toponymiques en Nouvelle-Calédonie - un Champ de Recherche Ouvert.' Enquêtes Rurales 14: 187-208. 
2012c. 'La Zone Voh-Koné-Pouembout.' In J. Banvallot and J.-C. Gay (eds), Atlas de la Nouvelle-Calédonie. Montpellier: IRD Editions.

— 2014. 'Fieldwork in a Context of Decolonization: The Example of a French Overseas Territory (New Caledonia).' Erdkunde 68: 251-264. doi.org/10.3112/erdkunde.2014.04.02

Langton, M. and O. Mazel, 2012. 'The Resource Curse Compared: Australian Aboriginal Participation in the Resource Extraction Industry and Distribution of Impacts.' In M. Langton and J. Longbottom (eds), Community Futures, Legal Architecture: Foundations for Indigenous Peoples in the Global Mining Boom. London: Routledge.

Leblic, I., 1993. Les Kanak Face au Développement: La Voie Étroite. Nouméa: Agence de Développement de la Culture Kanak/Presses Universitaires de Grenoble.

Le Meur, P.-Y., 2010. 'Réflexions sur un Oxymore: Le Débat du "Cadastre Coutumier" en Nouvelle-Calédonie.' In E. Faugère and I. Merle (eds), La Nouvelle-Calédonie, Vers un Destin Commun? Paris: Editions Karthala.

Le Meur, P.-Y., S. Grochain, M. Kowasch and D. Poithily, 2012. 'La SousTraitance Comme Interface: Rente Minière, Contrôle des Ressources et Arènes Locales en Nouvelle-Calédonie.' Nouméa: CNRT Nickel, Programme Gouvernance Minière (Document de Travail 10).

Le Meur, P.-Y. and T. Mennesson, 2011. 'Le Cadre Politico-Juridique Minier en Nouvelle-Calédonie: Mise en Perspective Historique.' Nouméa: CNRT Nickel, Programme Gouvernance Minière (Document de Travail 3).

Naepels, M., 1998. Histoires de Terres Kanak. Paris: Editions Belin.

—_ 2006. 'Réforme Foncière et Propriété dans la Région de Houaïlou (Nouvelle-Calédonie).' Etudes Rurales 177: 43-54.

Néaoutyine, P., 2006. L'Indépendance au Present: Identité Kanak et Destin Commun. Paris: Syllepse.

North Province, 2008. 'Etre Jeune en Province Nord: Vivre la Jeunesse.' Koné: Observatoire de la Santé et des Actions Sociales de la Province Nord. 
, 2013. 'Actualisation du Schéma Directeur d'Aménagement et d'Urbanisme (SDAU) des Zones de Voh, Koné, Pouembout et Poya.' Unpublished report.

Pitoiset, A., 2013. 'Interview in "Hebdo".' Nouvelle-Calédonie 1ère, 2026 April: $11-12$.

Pitoiset, A. and C. Wéry, 2008. Mystère Dang. Nouméa: Le Rayon Vert.

Poithily D., 2010. Les Stratégies et Motivations des Entrepreneurs VKP. Nouméa: Université de la Nouvelle-Calédonie (Masters thesis).

Robbins, P., 2006. 'Research Is Theft: Rigorous Enquiry in a Post-Colonial World.' In G. Valetine and S. Aitken (eds), Philosophies, People, Places and Practices. Thousand Oaks (CA): Sage.

Sachs, J. and A. Warner, 1995. 'Natural Resource Abundance and Economic Growth.' Cambridge (MA): National Bureau of Economic Research (Working Paper 5398).

Scholz, F., 2002. 'Die Theorie der Fragmentierenden Entwicklung.' Geographische Rundschau 10: 6-11.

Taylor, J. and B. Scambary, 2005. Indigenous People and the Pilbara Mining Boom: A Baseline for Regional Participation. Canberra: The Australian National University, Centre for Aboriginal Economic Policy Research (Research Monograph 25).

Tolia-Kelly D.P., 2006. 'Mobility/Stability: British Asian Cultures of "Landscape and Englishness".' Environment and Planning A 38: 341358. doi.org/10.1068/a37276

Winslow, D., 1995. 'Indépendance, Savoir Aborigène et Environnement en Nouvelle-Calédonie.' Journal of Political Ecology 2: 1-19. 
This text is taken from Large-scale Mines and Local-level Politics: Between New Caledonia and Papua New Guinea, edited by Colin Filer and Pierre-Yves Le Meur, published 2017 by ANU Press, The Australian National University, Canberra, Australia. 